\title{
Spatial Concentration of Land in Poland in 2002-2007
}

\author{
Alicja Mierosławska \\ Institute of Agricultural and Food Economics \\ National Research Institute \\ Warsaw, ul. Świętokraysk.a 20 \\ mieroslawska@ierigr.waw.pl
}

\begin{abstract}
The publication presents regional changes in the concentration of land in agricultural holdings in 2002 (before the accession of Poland to the $\mathrm{EU}$ ) and in 2007 (three years after the accession) in 16 regions (voivodeships) of Poland. The thesis was adopted that the integration of Poland with the EU contributed, among others, to the increase in the concentration of farmland.

To assess the level of concentration of land in a given Polish voivodeship, the Lorenz concentration ratio was used, which synthetically takes into consideration the degree of concentration of a number of holdings and of arable land in a given land-size group. The ratio was calculated on the basis of eight land-size groups of holdings: 1-5 ha, 5-10 ha, 10-15 ha, 15-20 ha, 20-30 ha, 30-50 ha, 50-100 and 100 or more ha.

The ranking of voivodeships was created according to the level of land concentration ratio in 2002 and 2007 and changes were determined between the years 2002-2007. In addition, the correlation ratio was calculated between the average size of a holding in a given voivodeship and the Lorenz concentration ratio, calculated for this voivodeship. The conducted analyses show that the concentration of arable land in the country has slightly increased, but in specific regions the changes were varied with the tendency towards convergence.
\end{abstract} Submitted: March, 2009 1 st revision: May, 2009

Keywords: agricultural holdings, arable land, Lorenz concentration ratio, regions/voivodeships

Accepted: June, 2009

JEL classification: Q1, O18, P1

\section{Introduction}

In the conditions of market economy and especially in the conditions of deepening integration and globalisation process, the basis for the functioning of every economic activity, including farming, is competitiveness. 
The problem of the improvement of competitiveness of our holdings became more visible when Poland took efforts to enter the EU, because it was known that our farming differed much from the EU farming in terms of land and labour productivity, which is a result of a much lower level of concentration and specialisation of agricultural production in our holdings. It was also known that only a radical improvement of the agrarian structure of Polish agricultural holdings, a significant progress in the implementation of new technologies of production and, in consequence, a drastic decrease of employment in agriculture can diminish the gap between Polish and EU agriculture.

The dynamics of change in the regional structure of agricultural holdings shortly after the integration was influenced not only by the structure of holdings prevailing at that time but also by the level of agrarian overpopulation and the situation of sectors surrounding agriculture enabling the outflow of workforce from farming. The possibilities of extending the size of holding varied, therefore, according to the region.

In order to compare the level of concentration of farmland in specific voivodeships, taking into account the degree of concentration of holdings and farmland in specific land-size groups, the Lorenz concentration ratio was calculated, the ratio used in the reports of the European Commission and of the ministries of agriculture of different countries of CentralEastern Europe, among which Poland ranks as last but one in terms of the ratio amounting to 54\% (Fabisiak A., 2005).

\section{The results of the study}

Since the beginning of the 1990s in the group of family holdings (dominating in Poland), a growing phenomenon of polarisation can be observed, with the creation of commercial farms on one hand with a tendency to increase the surface and scale of production and the existence of small-surface farms on the other (up to $5 \mathrm{ha}$ ) having little contact with the market. The increase in the share of large land-size groups in the general use of farmland takes place mostly at the expense of the medium-size farms (5-15 ha). There are large regional differences, however, in this respect.

As table 1 shows, the farmland concentration ratio has increased on average from $53 \%$ to $57.8 \%$ (i.e. by $4.8 \%$ ) in the entire country in the analysed period, what gives Poland a last but one position among the 10 new Member States, with the last country being Slovenia $42 \%$ (Fabisiak A. 2005). In specific voivodeships of Poland, the concentration ratio level in 2002 ranged from $20.1 \%$ in Małopolska to $87.2 \%$ in Pomorze (Pomerania).

The largest increase of the said ratio was noted in the following voivodeships: Zachodniopomorskie - increase by $23 \%$, Dolnośląskie - by $18.5 \%$ and Śląskie - by $13.3 \%$. Only in case of one voivodeship - Lubuskie - the concentration ratio did not change and in Podlaskie voivodeship it rose only by $1.4 \%$, confirming the phenomenon of the "hunger for land" known there. The visible deconcentration of farmland, however, was observed in three voivodeships: Łódzkie (the fall of the ratio by 30.8\%), Pomorskie (the fall by $22.2 \%$ ) and in Kujawsko-Pomorskie (the fall by $18.1 \%$ ).

In addition, the deconcentration trend was noted in voivodeships with the highest farmland concentration ratio in 2002 (i.e. in Pomorskie, Opolskie, Warmińsko-Mazurskie, Kujawsko-Pomorskie and Łódzkie).

Thus, in 2002-2007 the tendency was observed for the ratios of concentration of farmland in Polish regions to level out, as the level of concentration lowered in voivodeship of the highest concentration and increased in voivodeships of a fragmented agrarian structure. 
Table 1. The ranking of voivodeships in terms of farmland concentration ratio in 2007 and the changes in 2002-2007

\begin{tabular}{|c|l|c|c|c|}
\hline Position & \multicolumn{1}{|c|}{$\begin{array}{c}\text { The } \\
\text { Voivodeship }\end{array}$} & $\begin{array}{c}\text { The } \\
\text { ratio in 2002 in } \\
\%\end{array}$ & $\begin{array}{c}\text { concentration } \\
\text { ratio in 2007 } \\
\text { in \% }\end{array}$ & $\begin{array}{l}\text { Change in } \\
\text { percentage } \\
\text { points }\end{array}$ \\
\hline 1 & Zachodniopomorskie & 49.5 & 72.5 & 23.0 \\
\hline 2 & Opolskie & 82.7 & 71.7 & -11.0 \\
\hline 3 & Lubuskie & 71.6 & 71.5 & -0.1 \\
\hline 4 & Dolnośląskie & 51.0 & 69.5 & 18.5 \\
\hline 5 & Pomorskie & 87.2 & 65.0 & -22.2 \\
\hline 6 & Warmińsko-Mazurskie & 75.2 & 64.0 & -11.3 \\
\hline 7 & Wielkopolskie & 47.1 & 59.7 & 12.6 \\
\hline 8 & Kujawsko-Pomorskie & 74.6 & 56.5 & -18.1 \\
\hline 9 & Śląskie & 37.2 & 50.4 & 13.3 \\
\hline 10 & Mazowieckie & 43.8 & 47.0 & 3.2 \\
\hline 11 & Podlaskie & 44.8 & 46.2 & 1.4 \\
\hline 12 & Lubelskie & 38.5 & 46.1 & 7.5 \\
\hline 13 & Lódzkie & 73.6 & 42.9 & -30.8 \\
\hline 14 & Świętokrzyskie & 24.1 & 35.9 & 11.8 \\
\hline 15 & Podkarpackie & 37.4 & 35.4 & -2.0 \\
\hline 16 & Małopolskie & 20.1 & 27.9 & 7.8 \\
\hline & Poland & $\mathbf{5 3 . 0}$ & $\mathbf{5 7 . 8}$ & $\mathbf{4 . 8}$ \\
\hline & & & & \\
\hline
\end{tabular}

Source: Calculations of the author

The range between the concentration ratios of different voivodeships dropped from 4.3 in 2002 to 2.6 in 2007. This phenomenon can be attributed to the impact of different support programmes and credit lines for agricultural holdings (for the purchase of land, for young farmers, early retirement etc).

In result of the convergence process of farmland concentration taking place in Polish regions, caused by historical, as well as internal factors, the characteristics of farming in a given region/voivodeship in 2007 shaped as presented in table 2.

The largest surfaces of agricultural holding can currently be found in Zachodniopomorskie voivodeship, where the share of holdings larger than 30 ha of farmland is the highest and the share of population employed in farming, as well as the share of rural population is low and only higher than in the Sląskie (Silesian) voivodeship, which is the most industrialised region. 
Table 2. The most important characteristics of farming in a given Polish voivodeship

\begin{tabular}{|l|c|c|c|c|}
\hline Voivodeship & $\begin{array}{l}\text { The average } \\
\text { surface of } \\
\text { farmland in one } \\
\text { holding (1) }\end{array}$ & $\begin{array}{l}\text { \% of population } \\
\text { employed in } \\
\text { farming (2) }\end{array}$ & $\begin{array}{l}\% \text { of rural } \\
\text { population (3) }\end{array}$ & $\begin{array}{l}\text { of holdings } \\
\text { larger than 30 } \\
\text { ha of farmland } \\
(4)\end{array}$ \\
\hline Dolnośląskie & 2.96 & 8.2 & 29.0 & 6.4 \\
\hline Kujawsko-pom. & 14.27 & 17.7 & 38.61 & 8.2 \\
\hline Lubelskie & 6.94 & 37.6 & 53.4 & 1.8 \\
\hline Lubuskie & 14.27 & 9.1 & 35.9 & 6.3 \\
\hline Łódzkie & 7.00 & 20.9 & 35.3 & 1.5 \\
\hline Małopolskie & 3.92 & 17.6 & 50.4 & 0.3 \\
\hline Mazowieckie & 7.85 & 15.2 & 35.3 & 2.2 \\
\hline Opolskie & 15.03 & 16.7 & 47.4 & 7.8 \\
\hline Podkarpackie & 3.92 & 24.3 & 59.5 & 0.5 \\
\hline Podlaskie & 11.94 & 35.3 & 40.5 & 5.8 \\
\hline Pomorskie & 16.48 & 9.0 & 32.8 & 8.7 \\
\hline & 5.01 & 4.6 & 21.4 & 1.5 \\
\hline Świętokrzyskie & 5.01 & 32.5 & 64.7 & 0.6 \\
\hline Warm.-mazurskie & 20.93 & 16.6 & 40.0 & 13.8 \\
\hline Wielkopolskie & 13.24 & 16.7 & 43.0 & 6.2 \\
\hline Zachodniopomorskie & 25.94 & 9.0 & 30.9 & 14.5 \\
\hline POLAND & $\mathbf{8 . 7 6}$ & $\mathbf{1 6 . 6}$ & 38.6 & 3.6 \\
\hline
\end{tabular}

Source: Author's own compilation based on the data of the Central Statistical Office 2008

Summary and conclusions:

- The applied Lorenz concentration ratio shows the degree of concentration of farmland in agricultural holdings at the national, regional and local level and reflects changes taking place in the concentration process.

- The scope of agrarian changes in Polish farming is still insufficient and different according to the region. The concentration of farmland in the country in the years 2002-2007 increased to a small extent and varied in different regions.

- In 2002-2007 the tendency was observed for the ratios of concentration of farmland in Polish regions to level out, as the level of concentration lowered in voivodeships of the highest concentration and increased in voivodeships of a fragmented agrarian structure. The range of the concentration ratios of different voivodeships dropped from 4.3 in 2002 to 2.6 in 2007. This phenomenon can be attributed to the impact of different support programmes and credit lines for agricultural holdings (for the purchase of land, for young farmers, early retirement etc).

- The size of the holding is still the factor determining its economic size (measured in ESU), but not the only one as the importance of the equity factor rises.

- The further development of farming in many regions is caused by the increase in the possibility of the transfer of land to larger size holdings and lifting many barriers such as the regional milk quotas. 
- Because the pace of structural changes in Polish farming depends strongly on demographic processes, one can presume that the situation will change naturally only in a long-term perspective.

- Assigning a larger amount of funds for life-long payments for farmers who permanently give up farming on their land would boost the improvement of the fragmented agrarian structure of Polish farming.

- The results of the study should be helpful when preparing the strategy for the development of farming in the country, as well as in its specific regions, taking into consideration the differences in basic characteristics of farming in specific Polish regions.

\section{REFERENCES:}

1. Dzun W. (2007), Regional differences in the development of large agricultural holdings in the years 2002-2005, Publication in print of the Institute of Rural and Agricultural Development, Polish Academy of Sciences (IRWiR PAN), Warsaw

2. Fabisiak A. (2005), The changes in the area structure of holdings in Central and Eastern European countries, SERiA Scientific Yearbooks, vol. VII, book 1.

3. Central Statistical Office (GUS) (2007), GDP regional accounts in 2006

4. Central Statistical Office (GUS) (2007), Statistical yearbooks of voivodeships

5. Central Statistical Office (GUS) (2008), "Characteristics of agricultural holdings in 2008", CSO, Warsaw 2007.

6. Józwiak W. Today and tomorrow of agricultural holdings in the countries of Central and Eastern Europe, Multi-Annual Programme Report in print no. 98, IAFE-NRI, Warsaw 2008

7. Michna W., Chmielewska B., Mierosławska A. (2008), Multi-Annual Programme Report in print no. 94, IAFE-NRI, Warsaw

8. Collaborative work edited by M. Kłodziński (2008), Challenges ahead of rural areas and agriculture in the years 2014-2020, Institute of Rural and Agricultural Development, Polish Academy of Sciences (IRWIR), Warsaw

9. Sikorska A. with the research team (December 2008), The agricultural land market, status and perspectives, Report no. 11, IAFE-NRI, Warsaw

10. Ziętara W. (2008), Comments on the future of Polish holdings [in] Challenges ahead of rural areas and agriculture in the years 2014-2020, Institute of Rural and Agricultural Development, Polish Academy of Sciences (IRWIR), Warsaw 